\title{
Influence of Nitrogen Nutrition Management on Biomass Partitioning and Nitrogen Use Efficiency Indices in Hydroponically Grown Potato
}

\author{
Gregory D. Goins ${ }^{1}$ and Neil C. Yorio \\ Dynamac Corporation, Mail Code DYN-3, Kennedy Space Center FL, 32899
}

Raymond M. Wheeler

National Aeronautics and Space Administration, Mail Code YA-D3, Kennedy Space Center FL, 32899

\begin{abstract}
AdDitional INDEX words. Solanum tuberosum, tuber initiation, pH control, fertilization, nitrate, ammonium, electrical conductivity

Abstract. The National Aeronautics and Space Administration (NASA) has been conducting controlled environment research with potatoes (Solanum tuberosum $\mathrm{L}$.) in recirculating nutrient film technique (NFT)-hydroponic systems as a human life support component during long-duration spaceflight. Standard nutrient solution management approaches include constant $\mathrm{pH}$ regulation with nitric acid $\left(\mathrm{HNO}_{3}\right)$ and daily adjustment of electrical conductivity (EC) equivalent to half-strength modified Hoagland's solution, where nitrate $\left(\mathrm{NO}_{3}^{-}\right)$is the sole nitrogen $(\mathrm{N})$ source. Although tuber yields have been excellent with such an approach, $\mathrm{N}$ use efficiency indices are expected to be low relative to tuber biomass production. Furthermore, the high amount of $\mathrm{N}$ used in NFT-hydroponics, typically results in high inedible biomass, which conflicts with the need to minimize system mass, volume, and expenditure of resources for long-duration missions. More effective strategies of $\mathbf{N}$ fertilization need to be developed to more closely match $\mathbf{N}$ supply with demand of the crop. Hence, the primary objective of this study was to identify the optimal $N$ management regime and plant $N$ requirement to achieve high yields and to avoid inefficient use of $\mathrm{N}$ and excess inedible biomass production. In separate 84-day cropping experiments, three $\mathrm{N}$ management protocols were tested. Treatments which decreased $\mathrm{NO}_{3}^{--} \mathrm{N}$ supply indirectly through lowering nutrient solution EC (Expt. I), or disabling pH control, and/or supplying $\mathrm{NH}_{4}{ }^{+}-\mathrm{N}$ (Expt. III) did not significantly benefit tuber yield, but did influence $\mathrm{N}$ use efficiency indices. When supplied with an external 7.5 $\mathrm{mm} \mathrm{NO}_{3}^{--} \mathrm{N}$ for the first 42 days after planting (DAP), lowered to $1.0 \mathrm{~mm} \mathrm{NO}_{3}^{--} \mathrm{N}$ during the final 42 days (Expt. II), plants were able to achieve yields on par with plants which received constant $7.5 \mathrm{~mm} \mathrm{NO}_{3}^{--} \mathrm{N}$ (control). By abruptly decreasing $\mathrm{N}$ supply at tuber initiation in Expt. II, less $\mathrm{N}$ was taken up and accumulated by plants compared to those which received high constant $\mathbf{N}$ (control). However, proportionately more plant accumulated $\mathbf{N}$ was used (N use efficiency) to produce tuber biomass when $\mathbf{N}$ supply was abruptly lowered at tuber initiation in Expt. II. Hence, a hydroponic nutrient solution $\mathbf{N}$ management system may be modified to elicit greater plant $\mathbf{N}$-use while maintaining overall high tuber yield as opposed to achieving high tuber yields through excess $\mathrm{N}$ supply and shoot growth.
\end{abstract}

The National Aeronautics and Space Administration (NASA) has been conducting controlled environment agricultural experiments to evaluate the use of potatoes (Solanum tuberosum L.) in a life support system for humans in space (Wheeler et al., 1990). In these experiments, potato plants are grown either in pots containing peat-vermiculite potting mixtures or within recirculating nutrient film technique hydroponic (NFT) systems (Jones, 1997). When photosynthetically active radiation $(P A R)$, temperature, and atmospheric carbon dioxide $\left(\mathrm{CO}_{2}\right)$ concentration are maintained near optimal levels, plants cultured with this approach can produce tuber yields similar to record field yield (Wan et al., 1996; Wheeler et al., 1990). In recirculating NFT-studies with potatoes, the nutrient solution is typically managed with constant $\mathrm{pH}$ regulation using nitric acid $\left(\mathrm{HNO}_{3}\right)$ and daily adjustment of electrical conductivity (EC) equivalent to half-strength modified Hoagland's solution $\left(\approx 1.2 \mathrm{dS} \cdot \mathrm{m}^{-1}\right)$, where nitrate $\left(\mathrm{NO}_{3}{ }^{-}\right)$is the sole nitrogen $(\mathrm{N})$ source (Wheeler et al., 1999). This nutrient solution management regime likely errs on the side of over-application of $\mathrm{N}$, rather than risk $\mathrm{N}$ deficiency and reduced plant growth (Wheeler et al., 1999). Hence, the hydroponic nutrient solution management regime might be analogous to potato production on irrigated, coarse-textured fields where growers apply $\mathrm{N}$ in greater

Received for publication 21 Feb. 2003. Accepted for publication 26 Sept. 2003. ${ }^{1}$ To whom reprint request should be addressed: e-mail gregory.goins$1 @$ ksc.nasa.gov. amounts than any other nutrient (Mäck and Schjoerring, 2002; van Beusichem et al., 1988).

There is no consensus on the best $\mathrm{N}$ fertilization strategy for potato production (Westermann and Kleinkopf, 1985), given that $\mathrm{N}$ uptake and assimilation patterns differ substantially with different varieties (Zvomuya and Rosen, 2002), or in different environments (Davies, 2000; Mäck and Schjoerring, 2002; Sweetlove and Hill, 2000). However, it is generally accepted that when N supply is too low, total growth and final storage organ yield will decrease (Kleinkopf et al., 1981; Richards et al., 1990). Thus, it is a challenge to supply the optimal level of $\mathrm{N}$ for potatoes in an environmentally sound manner, given that reduction of $\mathrm{N}$ application can reduce yields (Alva et al., 2002; Lawlor, 2002). Hence, it is important to better understand processes that govern $\mathrm{N}$ uptake and biomass partitioning in potato crops, with respect to both environmental concerns (Gastal and Lemaire, 2002) and the quality of tubers (Waddell et al., 1999).

The role of $\mathrm{N}$ in potato nutrition and amount needed for crop growth and its ultimate fate have been the subject of numerous investigations, both in soil (Davies, 2000; Hegney and McPharlin, 2000) and hydroponic studies (Cao and Tibbitts, 1993,1998; Wheeler et al., 1990). Nitrogen is the dominant nutrient taken up by potato, and plant $\mathrm{N}$ requirements are greater than any other nutrient. Therefore, an adequate supply of plant-available $\mathrm{N}$ is crucial for high tuber yields. Although the quantity of $\mathrm{N}$ absorbed 
by potato plants depends on many variables, including the stage of plant growth, variety, and environmental conditions, it is generally assumed that tuber yield is enhanced by $\mathrm{N}$ application, whether in hydroponic culture (Cao and Tibbitts, 1998) or in the field (Errebhi et al., 1998). Modern cultivars demonstrate positive tuber yield response to high rates of applied N (Errebhi et al., 1999; Ewing and Struik, 1992; Struik et al., 1997). However, potato is generally regarded as an inefficient user of $\mathrm{N}$ partly due to shallow rooting (Lesczyhsik and Tanner, 1976; Roberts et al., 1992), and $\mathrm{N}$ not taken up by the potato crop may be leached into the groundwater (Gastal and Lemaire, 2002) in the field or lost to volatilization in hydroponic culture (Stutte, 1996). Especially on sandy coarse-textured soils, over fertilization with $\mathrm{N}$ increases the likelihood of contaminating groundwater resources (Richards et al., 1990; Struik et al., 1997). This is particularly true in irrigated potato areas where $\mathrm{NO}_{3}{ }^{-}$has been found in surveys of shallow observation wells (Klaseus et al., 1988).

Tuber initiation represents one of the most important stages of potato growth (Engels and Marschner, 1986). It has been suggested that reducing or withholding $\mathrm{N}$ until tubers initiate might increase the duration of tuber bulking, and so might improve final tuber yield (Westermann and Kleinkopf, 1985). Enhanced tuber yield has been demonstrated in the field when growers apply a portion of the total $\mathrm{N}$ fertilizer on a preplant basis and the remainder during the growing season (Hegney and McPharlin, 2000). During the early crop stages, $\mathrm{N}$ uptake favors canopy development (Mäck and Schjoerring, 2002). If $\mathrm{N}$ application is not excessive, $\mathrm{N}$ uptake at later crop stages favors tuber initiation and bulking. The rate of nitrate uptake increases during development of photosynthetic tissues (e.g., leaf expansion), but then declines during storage organ development (Imsande and Touraine, 1994). Collectively, these findings suggest that management of $\mathrm{N}$ availability with respect to crop growth phase could be a key factor in overall patterns of biomass partitioning between the shoot and tubers.

In hydroponic systems, the $\mathrm{pH}$ of the external nutrient solution must be systematically controlled to optimize nutrient availability, uptake, and plant yield. As often is the case in liquid culture, $\mathrm{N}$ is supplied solely as $\mathrm{NO}_{3}{ }^{-}$. Therefore, $\mathrm{HNO}_{3}$ is the popular choice for controlling $\mathrm{pH}$. Under these circumstances, plant nutrient uptake is heavily biased by anion supply, resulting in anion uptake typically exceeding cation uptake. Thus, plants extrude anion equivalents back into the solution to maintain electroneutrality (Raven, 1985). Use of $\mathrm{HNO}_{3}$ for $\mathrm{pH}$ control augments this charge imbalance condition, which can result in more than a third of the $\mathrm{N}$ supplied to the plant through $\mathrm{pH}$ control of the nutrient solution (Lea-Cox et al., 1996; Wheeler et al., 1990, 1999). During periods of rapid growth when there is heavy $\mathrm{NO}_{3}{ }^{-}-\mathrm{N}$ (i.e., anion) demand (Marshner, 1995), large additions of $\mathrm{HNO}_{3}$ are required to counter nutrient solution $\mathrm{pH}$ increase (Lea-Cox et al., 1996; Wheeler et al., 1999). To support a hectare of potatoes in recirculating NFT using exclusively $\mathrm{NO}_{3}{ }^{-}-\mathrm{N}$, it has been estimated that nearly $5 \mathrm{~L}$ of concentrated $\mathrm{HNO}_{3}$ would be required per day to control pH (Wheeler et al., 1990). Hence, $\mathrm{pH}$ control presents a considerable challenge to hydroponic system designs where nitrate is the sole source of $\mathrm{N}$.

Some researchers have suggested simultaneous addition of $\mathrm{NH}_{4}{ }^{-}-\mathrm{N}$ and $\mathrm{NO}_{3}{ }^{-} \mathrm{N}$ to the nutrient solution as a means to moderate $\mathrm{pH}$ fluctuations caused by the uptake of $\mathrm{N}$ when only $\mathrm{NO}_{3}^{--} \mathrm{N}$ is available (Lea-Cox et al., 1996). Using mixed $\mathrm{N}$ sources could mitigate charge imbalance, and reduce the amount of acid or base addition required for nutrient solution $\mathrm{pH}$ control. However, other studies have shown that ammonium concentrations in hydroponic solutions can inhibit $\mathrm{K}^{+}, \mathrm{Ca}^{2+}$, and $\mathrm{Mg}^{2+}$ uptake (Cao and Tibbitts, 1993). Because N uptake is high compared to other mineral elements in soilless culture, ionic balance is highly dependent on the uptake of N (Lea-Cox et al., 1996; Marshner, 1995). Therefore, replenishing nutrients in hydroponic systems through estimates of total salt concentration of solution, i.e., EC, could also result in excessive uptake of N (Savvas and Adamidis, 1999). In addition, a continuous excess supply of $\mathrm{N}$ to roots has been shown to delay tuber initiation and promote vegetative shoot growth (Krauss and Marschner, 1982).

Quite often there is difficulty reconciling potato $\mathrm{N}$ response results from field (Roberts et al., 1992) versus hydroponic culture (Cao and Tibbitts, 1998). However, particularly in hydroponic systems, $\mathrm{N}$ supply may be a useful means to manipulate partitioning between shoots and tubers (Ewing and Struik, 1992; Sweetlove and Hill, 2000). Limiting N concentration in solution could increase $\mathrm{N}$ use efficiency and tuber yield by suppressing shoot growth, and enhance assimilate partitioning into tubers. Remobilized assimilated N from the shoot could contribute to tuber bulking in lieu of a constant supply of high $\mathrm{N}$ from the nutrient solution. For controlled environment applications, it would be beneficial to know the optimal $\mathrm{N}$ management regime and plant $\mathrm{N}$ requirement to achieve high tuber yields while avoiding inefficient use of $\mathrm{N}$ through excess inedible biomass production. The current study was an attempt to better understand the processes that affect both potato crop $\mathrm{N}$ demand and rhizosphere $\mathrm{N}$ supply. We were particularly interested in manipulation of $\mathrm{N}$ supply relative to the crop growth phase following tuber initiation. Our main objective, therefore, was to quantify the effect of various $\mathrm{N}$ management practices on biomass partitioning and $\mathrm{N}$ use efficiency in hydroponically grown potato. A key element of this study was determining whether tuber dry mass gain was maintained in hydroponic systems when total nutrient levels (Expt. I), or $\mathrm{NO}_{3}^{--}$ $\mathrm{N}$ concentration (Expt. II) were allowed to decrease following tuber initiation as opposed to maintaining high nutrient levels or a constant elevated $\mathrm{N}$ supply over the duration of the crop growth cycle. This study also examined the importance of $\mathrm{pH}$ control and mixed N source (Expt. III) on potato productivity.

\section{Materials and Methods}

ENVIronmental CONDITIONS AND Plant CUlture. The study was carried out in a $1.8 \times 2.4 \mathrm{~m}$ walk-in growth chamber $(\mathrm{EGC}$ Inc., M-48, Chagrin, Falls, Ohio) using high-pressure sodium lamps with a 12-h photoperiod. Canopy-level photosynthetic photon flux $(P P F)$ levels were measured weekly and averaged $530 \pm 70 \mu \mathrm{mol} \cdot \mathrm{m}^{-2} \cdot \mathrm{s}^{-1}$ for all trays throughout the study. Growth chamber environmental conditions were maintained at $20^{\circ} \mathrm{C}( \pm$ $\left.0.5^{\circ} \mathrm{C}\right)$ day $/ 16^{\circ} \mathrm{C}\left( \pm 0.5^{\circ} \mathrm{C}\right)$ night air temperature, and constant $65 \%( \pm 5 \%)$ relative humidity. Atmospheric $\mathrm{CO}_{2}$ was maintained near $1200 \mu \mathrm{mol} \cdot \mathrm{mol}^{-1}(0.12 \mathrm{kPa})$ carbon dioxide. Plants were started from sterile nodal-propagated stem cuttings (Hussey and Stacey, 1981) of Solanum tuberosum 'Norland', an early-season red potato. Uniform plantlets were transplanted (two per tray) into slits of white/black plastic sheets that covered $0.25-\mathrm{m}^{2}$ plastic culture trays. Trays had a trapezoidal shape, which were 18 and $41 \mathrm{~cm}$ wide on the ends, $84 \mathrm{~cm}$ long, and $5 \mathrm{~cm}$ deep (Wheeler et al., 1990). Plants were grown using the nutrient film technique (NFT) where a film of nutrient solution was maintained $\approx 1 \mathrm{~cm}$ deep. The total solution volume of the reservoir was $\approx 20 \mathrm{~L}$. The nutrient solution (temperature $22 \pm 2{ }^{\circ} \mathrm{C}$ ) was continuously pumped from a single reservoir to two trays for each treatment at an ap- 
proximate flow rate of $1 \mathrm{~L} \cdot \mathrm{min}^{-1}$ per tray. The wide end of each tray was elevated $2 \mathrm{~cm}$ to allow passive flow of the solution to the narrower end where it was returned to the reservoir.

Nitrogen NUTRITION MANAGEMENT TREATMENTS. A series of three $\mathrm{N}$ nutrition management experiments were conducted based on a successful nutrient solution management approach typical for potatoes in NFT hydroponic system (Wheeler et al., 1999). Each experiment had four treatments with four replicate plants per treatment. Treatments in Expt. I involved managing $\mathrm{N}$ nutrition through daily manual adjustments of nutrient solution electrical conductivity (EC) at 1.2, 0.6, 0.3, or $1.2 \mathrm{dS} \cdot \mathrm{m}^{-1}$ (first $42 \mathrm{~d}$ ) $/ 0.3$ $\mathrm{dS} \cdot \mathrm{m}^{-1}$ (second $42 \mathrm{~d}$ ). The same modified Hoagland's (Arnon and Hoagland, 1940) starter solution (Table 1) and concentrated replenishment $(\approx 10 \times$ starter $)$ solution was used to maintain nutrient solution EC and replenish nutrients at the prescribed treatment level, while $\mathrm{pH}$ adjustment to 5.8 was constant via automatic addition of $0.4 \mathrm{M} \mathrm{HNO}_{3}$ or $0.4 \mathrm{M} \mathrm{KOH}$. Expt. II included treatments with different starter nutrient solutions of 7.5 (control), 3.0, 1.0 $\mathrm{mM} \mathrm{NO}_{3}{ }^{-}-\mathrm{N}$. In the final treatment in Expt. II, the nutrient solution was managed identically to the control for the first $42 \mathrm{~d}$, and then switched to $1.0 \mathrm{mM} \mathrm{NO}_{3}{ }^{-}-\mathrm{N}$ for the remaining $42 \mathrm{~d}$. In the 3.0 and $1.0 \mathrm{mM} \mathrm{NO}_{3}^{-}-\mathrm{N}$ treatments, the nutrient solution contained 1.75 $\mathrm{mm} \mathrm{CaCl}$ and $0.5 \mathrm{~mm} \mathrm{~K}_{2} \mathrm{SO}_{4}$, and $2.25 \mathrm{mM} \mathrm{CaCl}_{2}$ and $1.0 \mathrm{~mm}$ $\mathrm{K}_{2} \mathrm{SO}_{4}$, respectively. This facilitated consistent $\mathrm{K}^{+}$and $\mathrm{Ca}^{2+}$ counter ion concentrations across treatments, while $\mathrm{NO}_{3}{ }^{-}-\mathrm{N}$ supply varied according to prescribed treatment level. All treatments in Expt. II were maintained as the control with $\mathrm{EC}$ and $\mathrm{pH}$ levels at 1.2 $\mathrm{dS} \cdot \mathrm{m}^{-1}$ and 5.8 , respectively. Expt. III included treatments with and without $\mathrm{pH}$ adjustments, while growing plants in solutions containing either $7.5 \mathrm{mM} \mathrm{NO}_{3}-\mathrm{N}$ as the sole $\mathrm{N}$ source or mixed-N sources at a 1.5:1 ratio of $\mathrm{NO}_{3}-\mathrm{N}$ to $\mathrm{NH}_{4}-\mathrm{N}\left(3 \mathrm{~mm} \mathrm{Ca}\left(\mathrm{NO}_{3}\right)_{2}+\right.$ $1.5 \mathrm{~mm} \mathrm{KNO}_{3}: 3 \mathrm{~mm} \mathrm{NH}_{4} \mathrm{NO}_{3}$ ). To maintain equal $\mathrm{K}^{+}$an $\mathrm{Ca}^{2+}$ counter ion concentrations in mixed $\mathrm{N}$ treatments, starter solutions contained $1.0 \mathrm{mM} \mathrm{CaCl}_{2}$ and $0.5 \mathrm{mM} \mathrm{K}_{2} \mathrm{SO}_{4}$. All treatments in Expt. III were maintained with $\mathrm{EC}$ and $\mathrm{pH}$ levels at $1.2 \mathrm{dS} \cdot \mathrm{m}^{-1}$ and 5.8 (using $0.4 \mathrm{M} \mathrm{HNO}_{3}$ and $0.4 \mathrm{M} \mathrm{KOH}$ ), respectively. Daily records were kept for additions of water, acid, base, and concentrated nutrient replenishment solutions. On a weekly basis, nutrient solution $\mathrm{N}$ concentrations were tracked during the experiment by taking $200-\mathrm{mL}$ aliquot subsamples and performing automated colorimetric assays for nitrate and ammonium (US EPA-Method 600/4-79-020-350.1).

At $84 \mathrm{~d}$ after planting (DAP), plants were harvested and separated into shoots (leaves + stems), tubers, stolons, and roots. All tissues were oven-dried for at least $72 \mathrm{~h}$ at $70{ }^{\circ} \mathrm{C}$ and then weighed. Harvest index (HI) was calculated as tuber dry weight/ total plant dry weight. Plant tissue was ground in a Wiley Mill to pass through a $1.0 \mathrm{~mm}$ mesh screen. Total $\mathrm{N}$ concentration in shoots, tubers, and stolons + roots was determined by Dumas dry combustion on a Leco N/protein analyzer (St. Joseph, Missouri). Nitrogen uptake was calculated by multiplying the respective dry weights by the corresponding $\mathrm{N}$ concentrations. All indices of $\mathrm{N}$ use efficiency were based on $\mathrm{N}$ accumulation as measured at harvest (Moll et al., 1982). Nitrogen use efficiency indices were computed as follows:

$\mathrm{N}$ uptake efficiency $=($ total $\mathrm{N}$ uptake $/ \mathrm{N}$ supply $) \times 100$

$\mathrm{N}$ harvest index $=($ shoot + root or tuber $\mathrm{N}$ uptake/total $\mathrm{N}$ uptake $)$ $\times 100$

$\mathrm{N}$ utilization efficiency $=($ shoot + root, or tuber, dry weight $/$ total $\mathrm{N}$ uptake) $\times 100$

$\mathrm{N}$ use efficiency $=($ tuber or total dry weight/ $\mathrm{N}$ supply $) \times 100$

where total plant $\mathrm{N}$ was estimated by summing the shoot, tuber, and root (including stolon) N concentrations. Data were statistically analyzed using the GLM univariate procedure in SPSS (Windows release version 10.0.5). Differences among the control treatment mean and each of the other treatment means $(n=4)$ were compared using a two-sided posthoc Dunnett's pairwise multiple comparison $t$ test (Dunnett, 1955) at the 5\% level of significance.

\section{Results and Discussion}

Potato biomass Partitioning AND Yields. Within Expts. I, II, and III except for a few cases, tuber, shoot, root (includes stolon), and total plant dry weight yields (Table 2) were significantly greater in control plants (high constant $\mathrm{N}$ supply) as compared to the remaining plants given lower $\mathrm{N}$ supply. Typical $\mathrm{N}$ deficiency symptoms (diminutive, chlorotic canopies) were particularly evident in Expt. II where plants were supplied at the lowest $\mathrm{N}$ level through constant 3.0 or $1.0 \mathrm{~mm} \mathrm{NO}-\mathrm{N}$ for the entire cropping cycle. Because canopies associated with the low $\mathrm{N}$ treatments were shorter than the canopies receiving high $\mathrm{N}$ supply, influx of side lighting was mitigated by using neutral-density nylon mesh screens around the periphery of each tray (Went, 1957). The weekly measured $P P F$ (data not shown) difference between all treatments was slight $\left(530 \pm 70 \mu \mathrm{mol} \cdot \mathrm{m}^{-2} \cdot \mathrm{s}^{-1}\right)$, and appeared not to contribute significantly to observed treatment differences. Previous studies have shown that potato biomass yield can increase considerably in response to increasing $\mathrm{N}$ fertilization (Alva et al., 2002; Walker et al., 2001; Westermann and Kleinkopf, 1985; Zvomuya and Rosen, 2002). However, in terms of specific responses of tuber growth to $\mathrm{N}$ supply, data from previous studies have been inconsistent (Alva et al., 2002). Depending on the stage of crop growth, elevated $\mathrm{N}$ availability and uptake may

Table 1. Modified half-strength Hoagland's nutrient solution element concentrations in $\mathrm{NO}_{3}^{--} \mathrm{N}$ treatments.

\begin{tabular}{|c|c|c|c|c|c|c|c|c|c|c|c|c|c|}
\hline Reagent & & & & Con & $\mathrm{mM})$ & & & & & & $\operatorname{nen}(j$ & & \\
\hline source & $\mathrm{N}$ & $\mathrm{P}$ & $\mathrm{K}$ & $\mathrm{Ca}$ & $\mathrm{Mg}$ & $\mathrm{S}$ & $\mathrm{Cl}$ & $\mathrm{Fe}$ & $\overline{\mathrm{Mn}}$ & $\mathrm{Zn}$ & $\mathrm{Cu}$ & $\mathrm{B}$ & Mo \\
\hline$\overline{\mathrm{Ca}\left(\mathrm{NO}_{3}\right)_{2} \bullet 4 \mathrm{H}_{2} \mathrm{O}}$ & 5.0 & & & 2.5 & & & & & & & & & \\
\hline $\mathrm{KNO}_{3}$ & 2.5 & & 2.5 & & & & & & & & & & \\
\hline $\mathrm{MgSO}_{4} \cdot 7 \mathrm{H}_{2} \mathrm{O}$ & & & & & 1.0 & 1.0 & & & & & & & \\
\hline $\mathrm{FeCl}_{3} \cdot 4 \mathrm{H}_{2} \mathrm{O}$-EDTA & & & & & & & 0.15 & 0.05 & & & & & \\
\hline $\mathrm{H}_{3} \mathrm{BO}_{4}$ & & & & & & & & & & & & 9.5 & \\
\hline $\mathrm{CuSO}_{4} \cdot 5 \mathrm{H}_{2} \mathrm{O}$ & & & & & & & & & & & & 0.52 & \\
\hline$\left(\mathrm{NH}_{4}\right)_{6} \mathrm{Mo}_{7} \mathrm{O}_{24} \cdot 4 \mathrm{H}_{2} \mathrm{O}^{z}$ & & & & & & & & & & & & & 0.01 \\
\hline
\end{tabular}

2Trace $\mathrm{NH}_{4}$ concentrations below detection limits $(<0.01 \mu \mathrm{M})$. 
Table 2. Tuber number, harvest index and tuber, shoot, and root dry weight from potato plants grown in nutrient solutions with different electrical conductivities (ECs), $\mathrm{NO}_{3}{ }^{-}-\mathrm{N}$ concentrations, or form of $\mathrm{N}$ with and without $\mathrm{pH}$ management.

\begin{tabular}{|c|c|c|c|c|c|c|c|}
\hline \multirow[b]{2}{*}{ Treatment } & \multicolumn{2}{|c|}{ Tubers/plant } & \multicolumn{4}{|c|}{ Dry wt (g/plant) } & \multirow{2}{*}{$\begin{array}{c}\begin{array}{c}\text { Harvest } \\
\text { index }(\%)\end{array} \\
\text { Tuber }\end{array}$} \\
\hline & $<2.5$ & $>2.5$ & Shoot & Tuber & Rooty & Total plant & \\
\hline \multicolumn{8}{|l|}{$\overline{\text { Expt. I }}$} \\
\hline 0.3 & $48^{*}$ & $21^{*}$ & $28^{*}$ & $144^{*}$ & $3^{*}$ & $175^{*}$ & $82^{*}$ \\
\hline 0.6 & 20 & $26^{*}$ & $44^{*}$ & $189^{*}$ & $4^{*}$ & $237^{*}$ & $80^{*}$ \\
\hline $1.2 / 0.3$ & $25^{*}$ & 32 & $60^{*}$ & $215^{*}$ & 8 & $283^{*}$ & 76 \\
\hline \multicolumn{8}{|l|}{$\begin{array}{l}\text { Expt. II } \\
\qquad\left[\mathrm{NO}_{3}{ }^{-}-\mathrm{N}\right](\mathrm{mm})\end{array}$} \\
\hline 1.0 & $9^{*}$ & $10^{*}$ & $9^{*}$ & $47^{*}$ & $2^{*}$ & $58^{*}$ & $81^{*}$ \\
\hline 3.0 & 24 & $15^{*}$ & $20^{*}$ & $114^{*}$ & $3^{*}$ & $137^{*}$ & $83^{*}$ \\
\hline $7.5 / 1.0$ & $42^{*}$ & 34 & $58^{*}$ & 226 & 7 & $291^{*}$ & 78 \\
\hline (Control) 7.5 & 22 & 31 & 83 & 252 & 7 & 342 & 74 \\
\hline (Control) $\mathrm{NO}_{3}^{-}-\mathrm{N}, \mathrm{pH}$ management & 26 & 28 & 76 & 197 & 6 & 279 & 71 \\
\hline
\end{tabular}

*Significant difference between the control mean and the respective $\mathrm{N}$ nutrient management treatment means $(\mathrm{n}=4)$ within a column for each experiment according to Dunnett's procedure $(\alpha=0.05)$.

yRoots include stolons.

not result in a tuber yield increase (Westermann and Kleinkopf, 1985). Results from our study showed no significant difference in tuber or root dry weight between control plants compared to plants supplied with $7.5 \mathrm{~mm} \mathrm{NO}{ }^{-}-\mathrm{N}$ the first $42 \mathrm{~d}$ followed by $1.0 \mathrm{~mm} \mathrm{NO}_{3}^{-}-\mathrm{N}$ for the last $42 \mathrm{~d}$ before harvest. This suggests plants given reduced $\mathrm{NO}_{3}^{-}-\mathrm{N}$ supply after tuber initiation could sustain as much tuber dry weight gain as control plants supplied with constant $7.5 \mathrm{~mm} \mathrm{NO}_{3}^{-}-\mathrm{N}$ during the entire cropping cycle. Apparently, $7.5 \mathrm{~mm} \mathrm{NO}-\mathrm{N}$ during the first 42 DAP represented sufficient $\mathrm{N}$ supply to establish an adequate amount of canopy area for light capture and photosynthate accumulation (Sweetlove and Hill, 2000). In addition, the tuber yield data for these same plants suggest that for posttuber initiation, $1.0 \mathrm{~mm} \mathrm{NO}_{3}^{-}-\mathrm{N}$ was sufficient $\mathrm{N}$ supply combined with internal plant $\mathrm{N}$ from source above ground tissues to produce tuber yield equivalent to the control plants (Sweetlove and Hill, 2000). Daily additions of $\mathrm{HNO}_{3}$ and replenishment solution (data not shown) showed that $\approx 90 \%$ of the total supplied $\mathrm{N}$ (Table 3) in Expt. II was furnished to the 7.5/1.0 mм $\mathrm{NO}_{3}^{-}-\mathrm{N}$ nutrient solution before 42 DAP, whereas only $56 \%$ of the total supplied $\mathrm{N}$ was added by that same time in the control (constant $7.5 \mathrm{~mm} \mathrm{NO}_{3}^{-}-\mathrm{N}$ ). This suggests that at least $20 \%$ more $\mathrm{N}$ was added to the control nutrient solution perhaps in excess of that required to achieve an equivalent tuber yield with a lower posttuber initiation $\mathrm{NO}_{3}{ }^{-}-\mathrm{N}$ supply. This finding agreed with previous work that showed that shoot growth is preferentially stimulated under high $\mathrm{NO}_{3}^{-}-\mathrm{N}$ supply, whereas tuber growth is stimulated under certain $\mathrm{NO}_{3}^{--} \mathrm{N}$ limiting conditions (Mäck and Schjoerring, 2002). By reducing $\mathrm{NO}_{3}{ }^{-} \mathrm{N}$ supply following tuber initiation, the overall sink strength of the shoot may have been lowered, and $\mathrm{N}$ export from the shoot to tubers may have been enhanced (McDonald et al., 1996). On the other hand, treatments which manipulated $\mathrm{NO}_{3}^{-}-\mathrm{N}$ supply indirectly through lowering nutrient solution EC (Expt. I), or disabling pH control and/or supplying a mixed-N source (Expt. II) did not significantly benefit tuber yield. Overall $\mathrm{N}$ supply to the control plants was at least $40 \%$ greater compared to those treatments in which $\mathrm{N}$ supply was reduced via nutrient solution EC (Expt. I) or disabled $\mathrm{pH}$ with or without mixed $\mathrm{N}$ form (Expt. III). These $\mathrm{N}$ supply reduction methods were apparently too drastic to produce tuber yields at the level of each control.

Decreasing nutrient solution EC (Expt. I) or supplying mixed $\mathrm{N}$ forms (Expt. III) significantly increased the number of small tubers (Table 2), while decreasing the number of large tubers. In Expt. II, the 7.5/1.0 $\mathrm{NO}_{3}^{-}-\mathrm{N}$ treatment produced an equivalent number of large tubers and nearly twice as many small tubers as the control plants. At low constant $\mathrm{NO}_{3}^{-}-\mathrm{N}$ supply in Expt. II, both small and large tuber numbers decreased drastically. High $\mathrm{N}$ levels at planting can increase production of small tubers and decrease production of large tubers (Errebhi et al., 1998; Westermann and Kleinkopf, 1985), possibly because of a delayed initiation response. It is noteworthy that a sudden change in $\mathrm{N}$ supply as opposed to a steady-state $\mathrm{N}$ supply has been linked with modifications in cytokinin phytohormone balance in potato (Sattelmacher and Marschner, 1978), which may have played a role in observed differences in tuber initiation. Increasing the proportion of $\mathrm{N}$ applied at planting for certain potato cultivars grown on sandy soils increases the yield of undesirable tubers and tends to reduce yield of marketable tubers (Errebhi et al., 1998; Westermann and Kleinkopf, 1985). In comparison to the controls in the present study, overall tuber biomass relative to total plant biomass (harvest index) was significantly greater when EC was lowered (Expt. I), when constant $\mathrm{NO}_{3}^{-}-\mathrm{N}$ supply was reduced (Expt. II), and when $\mathrm{NH}_{4}{ }^{+}-\mathrm{N}$ was present (Expt. III) with or without $\mathrm{pH}$ control. This suggests that tuber biomass harvest index was increased by reducing overall $\mathrm{N}$ supply directly or indirectly, irrespective of $\mathrm{N}$ management regime. For the most part, reduced $\mathrm{N}$ supply boosted tuber biomass and harvest index by means of lowered shoot biomass amounts combined with increased production of small tubers.

NitRogen UPTAKE EFFICIENCY AND HARVEST INDEX. $N$ uptake efficiency (Table 3) reflects the proportion of total $\mathrm{N}$ taken up by the whole plant and accumulated relative to $\mathrm{N}$ supplied. In 
terms of $\mathrm{N}$ management regime, there were no appreciable trends for $\mathrm{N}$ uptake efficiency among treatments within any experiments, with one exception. The lowest $\mathrm{N}$ uptake efficiency was observed in the treatment (Expt. II) where $\mathrm{NO}_{3}{ }^{-}-\mathrm{N}$ supply was lowered following tuber initiation as opposed to the remaining treatments which received steady-state $\mathrm{N}$ supply. An abrupt change in $\mathrm{NO}_{3}{ }^{-}-\mathrm{N}$ supply following tuber initiation may have induced changes in remobilization and translocation dynamics between the shoot and developing tubers relative to internal plant $\mathrm{N}$ reserves (Lawlor, 2002; Sweetlove and Hill, 2000). Previous research has demonstrated that $\mathrm{N}$ export from the shoot to tubers is enhanced as a result of reducing $\mathrm{NO}_{3}{ }^{-} \mathrm{N}$ supply (McDonald et al., 1996). Other studies have found that uptake of $\mathrm{N}\left(\mathrm{NO}_{3}{ }^{-}\right.$or $\mathrm{NH}_{4}^{+}$) in solution culture studies (Saravitz et al., 1998) or in the field (Devienne-Barret et al., 2000) depends on $\mathrm{N}$ level in the nutrient solution or soil. In the present study, nitrogen $\left(\mathrm{NO}_{3}{ }^{-}\right.$or $\mathrm{NH}_{4}^{+}$) was taken up rapidly by plants following replenishment rather than accumulating in the nutrient solutions (Jones, 1997). Weekly analysis of the bulk nutrient solutions (data not shown) prior to replenishment showed $\mathrm{NO}_{3}{ }^{-} \mathrm{N}$ and $\mathrm{NH}_{4}{ }^{+}-\mathrm{N}$ concentrations to be very low $(<0.25 \mathrm{~mm} \mathrm{~N})$, irrespective of high or low $\mathrm{N}$ supply regime. Related hydroponic studies have also shown rapid depletion of $\mathrm{N}$ from the nutrient solution despite $\mathrm{N}$ being in the highest concentration in the starter and replenishment nutrient solutions (Jones, 1997; Lea-Cox et al., 1996; Wheeler et al., 1990). When compared to $\mathrm{N}$ uptake efficiencies observed in the field (Roberts et al., 1991, 1992), except for the aforementioned 7.5/3.0 mm $\mathrm{NO}_{3}{ }^{-}-\mathrm{N}$ case (Expt. II), $\mathrm{N}$ uptake efficiencies in all our hydroponic treatments (Table 3), were much greater. The highest $\mathrm{N}$ uptake efficiency by potatoes in field studies is estimated around 65\% (Roberts et al., 1991). Field N uptake efficiencies are expected to be lower than hydroponic systems due to $\mathrm{N}$ loss from leaching below the root zone (Devienne-Barret et al., 2000), especially on coarse-textured soils under heavy rain or high irrigation (Errebhi et al., 1998). High $\mathrm{N}$ recovery in the field, is associated with better tuber yield and quality (Waddell et al., 1999; Westermann et al., 1988; Zvomuya and Rosen, 2002). In recirculating hydroponic culture, leaching losses are not a concern, but rapid uptake of $\mathrm{N}$ in the plant system can reduce the potential for $\mathrm{N}$ loss thorough microbially mediated denitrification and volatilization (Stutte, 1996).

The proportion of $\mathrm{N}$ partitioned to tubers relative to the total $\mathrm{N}$ in the whole plant, known as tuber $\mathrm{N}$ harvest index (Table 3), tended to decline as $\mathrm{NO}_{3}{ }^{-}-\mathrm{N}$ supply increased in Expts. I and II. Interestingly, the opposite trend was apparent in terms of shoot + root (inedible tissues) $\mathrm{N}$ harvest index in Expts. I and II, where proportionately more $\mathrm{N}$ taken up was recovered in the shoot and root tissues as $\mathrm{NO}_{3}-\mathrm{-}$ - supply increased. Compared to treatments receiving low $\mathrm{N}$ supply, plants receiving elevated $\mathrm{NO}_{3}^{-}-\mathrm{N}$ supply produced significant quantities of shoot biomass, which appeared to accumulate $\mathrm{NO}_{3}{ }^{-}-\mathrm{N}$. This is significant in that accumulation of $\mathrm{NO}_{3}$ - in the shoot has been shown to act as a signal to regulate shoot-root photosynthate allocation in plants. The same N supply response relative to $\mathrm{N}$ harvest indices were not observed when mixed $\mathrm{N}$ forms were supplied. Unlike ammonium $\mathrm{N}$, nitrate $\mathrm{N}$ is stored in the plant when uptake exceeds its reduction and subsequent assimilation capacity. Under ample $\mathrm{NO}_{3}^{-}-\mathrm{N}$ availability, a large proportion of $\mathrm{N}$ is stored (metabolically inactive) as protein, and to a lesser extent, as amino acids and $\mathrm{NO}_{3}^{-}-\mathrm{N}$ in short or long-term pools in the vacuole (Djennane et al., 2002; Lawlor, 2002).

Nitrogen USE EFFICIENCY. Nitrogen use efficiency (Table 4), also known as physiologic $\mathrm{N}$ use efficiency (Zvomuya and Rosen, 2002), relates plant dry weight gain per unit of $\mathrm{N}$ taken up and accumulated in the whole plant. In all experiments, tuber $\mathrm{N}$ use efficiency (Table 4) generally decreased as $\mathrm{N}$ uptake (Table 3) increased. This trend was not always observed for $\mathrm{N}$ use efficiency relative to inedible biomass (shoot, stolon, root) across experiments. However, total plant $\mathrm{N}$ use efficiency generally decreased as more $\mathrm{N}$ was taken up, irrespective of $\mathrm{N}$ management treatment across experiments. It is important to note that tuber $\mathrm{N}$ use efficiency was significantly lower in control plants as compared

Table 3. Nitrogen supply, $\mathrm{N}$ uptake, and $\mathrm{N}$ harvest index from potato plants grown in nutrient solution with different electrical conductivities (ECs), $\mathrm{NO}_{3}{ }^{-}-\mathrm{N}$ concentrations, or form of $\mathrm{N}$ with and without $\mathrm{pH}$ management.

\begin{tabular}{|c|c|c|c|c|c|c|c|}
\hline \multirow[b]{2}{*}{ Treatment } & \multirow{2}{*}{$\begin{array}{l}\text { N supply } \\
\text { (g/plant) }\end{array}$} & \multicolumn{3}{|c|}{$\mathrm{N}$ uptake (g/plant) } & \multirow{2}{*}{$\begin{array}{c}\begin{array}{c}\mathrm{N} \text { uptake } \\
\text { efficiency }(\%)\end{array} \\
\text { Total plant }\end{array}$} & \multicolumn{2}{|c|}{$\mathrm{N}$ harvest index $(\%)$} \\
\hline & & Shoot & Tuber & Rooty & & Shoot + root & Tuber \\
\hline \multicolumn{8}{|l|}{$\overline{\text { Expt. I }}$} \\
\hline 0.3 & 3.3 & $0.7^{*}$ & $2.3^{*}$ & $0.10^{*}$ & 93.4 & $25.4^{*}$ & $74.6^{*}$ \\
\hline 0.6 & 5.5 & $1.0^{*}$ & $3.1^{*}$ & 0.20 & $78.2^{*}$ & $27.9^{*}$ & $72.1^{*}$ \\
\hline $1.2 / 0.3$ & 5.7 & $1.8^{*}$ & $3.6^{*}$ & 0.21 & 98.4 & $35.8^{*}$ & $64.2^{*}$ \\
\hline \multicolumn{8}{|l|}{$\begin{array}{l}\text { Expt. II } \\
{\left[\mathrm{NO}_{3}{ }^{-}-\mathrm{N}\right](\mathrm{mm})}\end{array}$} \\
\hline 1.0 & 1.0 & $0.2^{*}$ & $0.5^{*}$ & $0.04^{*}$ & $71.0^{*}$ & $28.2^{*}$ & $71.8^{*}$ \\
\hline 3.0 & 1.6 & $0.5^{*}$ & $0.9^{*}$ & $0.09^{*}$ & 91.1 & $38.2^{*}$ & 61.8 \\
\hline $7.5 / 1.0$ & 7.4 & $1.8^{*}$ & $2.8^{*}$ & 0.20 & $64.9^{*}$ & 41.7 & 58.3 \\
\hline (Control) 7.5 & 9.1 & 3.7 & 4.3 & 0.21 & 90.2 & 47.6 & 52.4 \\
\hline (Control) $\mathrm{NO}_{3}{ }^{-}-\mathrm{N}, \mathrm{pH}$ management & 7.1 & 2.6 & 3.2 & 0.22 & 85.0 & 47.0 & 53.0 \\
\hline
\end{tabular}

*Significant difference between the control mean and the respective $\mathrm{N}$ nutrient management treatment means $(\mathrm{n}=4)$ within a column for each experiment according to Dunnett's procedure $(\alpha=0.05)$.

yRoots include stolons. 
Table 4. Nitrogen use efficiency from potato plants grown in nutrient solutions with different electrical conductivities $\left(\mathrm{ECs}^{-}\right), \mathrm{NO}_{3}^{--} \mathrm{N}$ concentrations, or form of $\mathrm{N}$ with and without $\mathrm{pH}$ management.

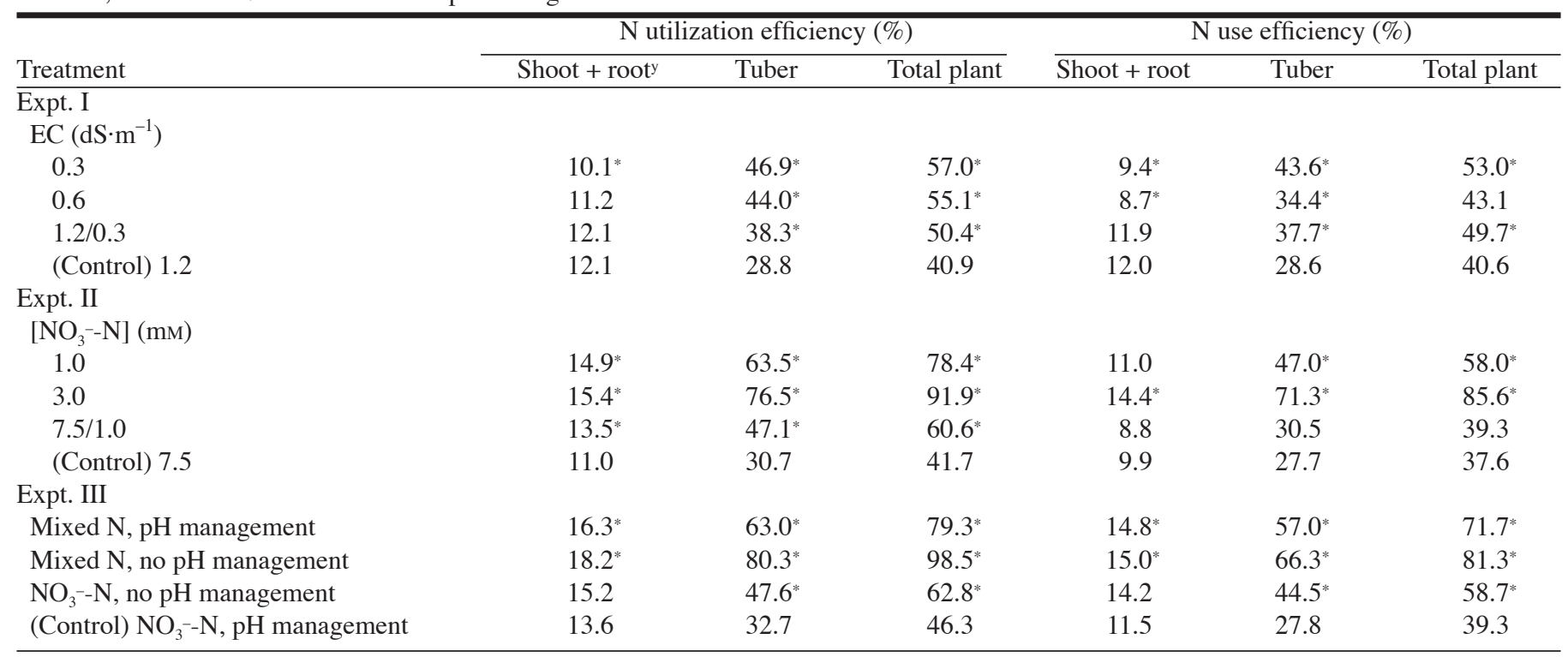

*Significant difference between the control mean and the respective $\mathrm{N}$ nutrient management treatment means $(\mathrm{n}=4)$ within a column for each experiment according to Dunnett's procedure $(\alpha=0.05)$.

yRoots include stolons.

to the 7.5/1.0 $\mathrm{NO}_{3}^{-}-\mathrm{N}$ (Expt. II) plants, yet the tuber dry weight yields were not significantly different. Hence, constant elevated $\mathrm{NO}_{3}^{--} \mathrm{N}$ supply (controls) appeared to enhance uptake of $\mathrm{N}$ (Table 3) without commensurate enhancement of tuber dry weight gain. Therefore, as more $\mathrm{N}$ was taken up by plants (Table 3), less $\mathrm{N}$ was proportionately partitioned to tubers, while more $\mathrm{N}$ was directed into inedible biomass, mostly represented by shoot tissue. Perhaps this can be attributed to an earlier tuber initiation observed in plants that received lower $\mathrm{N}$ supply. Since all plants were harvested at 84 DAP, irrespective of treatment, plants under high $\mathrm{N}$ supply (Table 3) may have experienced a shorter tuber bulking phase. Delayed tuber initiation can decrease yield when the time interval between planting and harvesting is not extended to accommodate the bulking phase (Krauss and Marschner, 1982). Conversely, under low N supply, more time between tuber initiation and harvest could have enhanced photosynthate accumulation in tubers.

Total plant and tuber $\mathrm{N}$ use efficiency data (Table 4), which reflects the proportion of total plant or tuber dry weight yield relative to $\mathrm{N}$ supplied, showed the same general trends as $\mathrm{N}$ use efficiency across treatments in different experiments. In other words, as more $\mathrm{N}$ was supplied (Table 3 ) and accumulated mainly in the shoot tissue (Table 3), both total plant $\mathrm{N}$ and tuber $\mathrm{N}$ use efficiency (Table 4) decreased. These findings agreed with a common notion that high $\mathrm{N}$ supply promotes new leaf tissue growth (Gastal and Lemaire, 2002), often at the expense of storage organs (Westermann and Kleinkopf, 1985; Westermann et al., 1988). There is an apparent trade-off between allocation of $\mathrm{N}$ to maintain photosynthetic activity of existing leaves, and storage organ dry weight gain (Sweetlove and Hill, 2000). During early plant growth and development, uptake of $\mathrm{N}$ is mostly used in the expansion of leaves and roots which efficiently assimilate inorganic $\mathrm{N}$ for amino acid and protein synthesis (Lawlor, 2002). During the crop remobilization phase, leaves become a net source and translocate photosynthates to developing storage organs (Lawlor, 2002; Sweetlove and Hill, 2000). Certain potato cultivars may exhibit stronger competition between source leaves and tuber sinks relative to other cultivars after the onset of tuber initiation under high supply N (Engels and Marschner, 1986; Mäck and Schjoerring, 2002). Tuber growth may also depend on its competing strength for photosynthates (Mäck and Schjoerring, 2002). The exact mechanisms controlling responses to $\mathrm{N}$ vary and depend on the relative availability of $\mathrm{N}$ from internal reserves and from external sources of nitrate (Walker et al., 2001).

In conclusion, regardless of $\mathrm{N}$ manipulation treatment, total plant and tuber $\mathrm{N}$ use and $\mathrm{N}$ use efficiencies decreased, and tuber yield increased as more $\mathrm{N}$ was supplied and taken up by the plants. However, compared to plants receiving constant high $\mathrm{N}$ supply, total plant and tuber $\mathrm{N}$ use efficiency increased significantly when plants were given an initial high constant $\mathrm{N}$ supply, lowered to a modest $\mathrm{NO}_{3}^{-}-\mathrm{N}$ supply posttuber initiation. Apparently, high constant $\mathrm{N}$ supply during early growth was adequate for plants to accumulate sufficient internal $\mathrm{N}$ reserve capacity to sustain high tuber yields in the presence of low external $\mathrm{NO}_{3}^{-}-\mathrm{N}$ supply posttuber initiation. Treatments that lowered $\mathrm{NO}_{3}^{-}-\mathrm{N}$ supply indirectly through lowering nutrient solution $\mathrm{EC}$, or disabling $\mathrm{pH}$ control, and/or supplying $\mathrm{NH}_{4}{ }^{+} \mathrm{N}$ did not significantly benefit tuber yield, but did influence $\mathrm{N}$ use efficiency indices, largely via reduced shoot biomass. These findings suggest that a high constant $\mathrm{N}$ supply in hydroponic culture promoted high tuber yield in combination with abundant inedible biomass production, which lowered $\mathrm{N}$ use indices relative to tubers. Additional study of the physiological factors influencing the uptake and use of $\mathrm{N}$ in potatoes will help develop more efficient management strategies of $\mathrm{N}$ supply in hydroponic culture.

\section{Literature Cited}

Alva, A.K., T. Hodges, A. Boydston, and H.P. Collins. 2002. Dry matter and nitrogen accumulations and partitioning in two potato cultivars. $\mathrm{J}$. Plant Nutr. 25:1621-1630.

Arnon, D.I. and D.R. Hoagland. 1940. Crop production in artificial culture solutions and in soils with special reference to factors controlling yields and absorption of inorganic nutrients. Soil Sci. 50:463-485.

Cao, W. and T.W. Tibbitts. 1993. Study of various $\mathrm{NH}_{4}{ }^{+} / \mathrm{NO}_{3}{ }^{-}$mixtures for enhancing growth of potatoes. J. Plant Nutr. 16:1691-1704. 
Cao, W. and T.W. Tibbitts. 1998. Response of potatoes to nitrogen concentrations differ with nitrogen forms. J. Plant Nutr 21:615-623.

Davies, C. 2000. Strategy differences of two potato species in response to nitrogen starvation. Do plants have a genetic switch for nitrogen signaling? Plant Cell Environ. 23:759-765.

Devienne-Barret, F., E. Justes, J.M. Machet, and B. Mary. 2000. Integrated control of nitrate uptake by crop growth rate and soil nitrate availability under field conditions. Ann. Bot-London 86:995-1005.

Djennane, S., J.E. Chauvin, and C. Meyer. 2002. Glasshouse behavior of eight transgenic potato clones with a modified nitrate reductase expression under two fertilization regimes. J. Expt. Bot. 53:1037-1045.

Dunnett, C.W. 1955. A multi-comparisons procedure for comparing several treatments with a control. J. Amer. Stat. Assocn. 50:1096-1121.

Engels, C.H. and H. Marschner. 1986. Allocation of photosynthate to individual tubers of Solanum tuberosum L. II. Relationship between growth rate, carbohydrate concentration and ${ }^{14} \mathrm{C}$-partitioning within tubers. J. Expt. Bot. 37:1804-1812.

Errebhi, M., C.J. Rosen, S.C. Gupta, and D.E. Birong. 1998. Potato yield response and nitrate leaching as influenced by nitrogen management. Agron. J. 90:10-15.

Errebhi, M., C.J. Rosen, F. Lauer, M.W. Martin, and J.B. Bamberg. 1999. Evaluation of tuber-bearing Solanum species for nitrogen use efficiency and biomass partitioning. Amer. J. Potato Res. 76:143-151.

Ewing, E.E. and P.C. Struik. 1992. Tuber formation in potato: Induction, initiation, and growth. Hort. Rev. 14:89-198.

Gastal, F. and G. Lemaire. 2002. N uptake and distribution in crops: an agronomical and ecophysiological perspective. J. Expt. Bot. 53: 789-799.

Hegney, M.A. and I.R. McPharlin. 2000. Response of summer-planted potatoes to level of applied nitrogen and water. J. Plant Nutr. 23:197-218.

Hussey, G. and N.J. Stacey. 1981. In vitro propagation of potato (Solanum tuberosum L.). Ann. Bot.-London 48:787-796.

Imsande, J. and B. Touraine. 1994. N demand and the regulation of nitrate uptake. Plant Physiol. 105:3-7.

Jones, J. B. 1997. Hydroponics - A practical guide for the soiless grower. St. Lucie Press, Boca Raton, Fla.

Klaseus, T.G., G.C. Buzicky, and E.C. Schneider. 1988. Pesticides and groundwater: Surveys of selected Minnesota wells. Report of the Legislative Commission on Minnesota Resources. Minn. Dept. Health, Minn. Dept. Agr., St. Paul.

Kleinkopf, G. E., D.T. Westermann, and R.B. Dwelle. 1981. Dry matter production and nitrogen utilization by six potato cultivars. Agron J. 73:799-802.

Krauss, A. and H. Marschner. 1982. Influence of nitrogen nutrition, daylength and temperature on contents of gibberellic and abscisic acid on tuberization in potato plants. Potato Res. 25:13-21.

Lawlor, D.W. 2002. Carbon and nitrogen assimilation in relation to yield: Mechanisms are the key to understanding production systems. J. Expt. Bot. 53:773-787.

Lea-Cox, J.D., G.W. Stutte, W.L. Berry, and R.M. Wheeler. 1996. Charge balance-A theoretical basis for modulating $\mathrm{pH}$ fluctuations in plant nutrient delivery systems. Life Support Biosphere Sci. 3:53-59.

Lesczyhsik, D.B. and C.B. Tanner. 1976. Seasonal variation of root distribution of irrigated field grown Russert Burbank potato. Amer. Potato J. 53:69-78.

Mäck, G. and J.K. Schjoerring. 2002. Effect of $\mathrm{NO}_{3}-$ supply on $\mathrm{N}$ metabolism of potato plants (Solanum tuberosum L.) with special focus on the tubers. Plant Cell Environ. 25:999-1009.

Marshner, H. 1995. Ion uptake mechanisms of individual cells and roots. In: H. Marshner (ed.). Mineral nutrition of higher pants, 2nd ed. Academic Press, New York.

McDonald, A.J.S., T. Ericsson, and C.M. Larsson. 1996. Plant nutrition, dry matter gain and partitioning at the whole-plant level. J. Expt. Bot.
47:1245-1253.

Moll, R.H., E.J. Kamprath, and W.A. Jackson. 1982. Analysis and interpretation of factors which contribute to efficiency of nitrogen utilization. Agron J. 74:562-564.

Raven, J.A. 1985. Regulation of $\mathrm{pH}$ and generation of osmolarity in vascular plants: Costs and benefits in relation to efficiency of use of energy, nitrogen, and water. New Phytol. 101:25-77.

Richards, J.E., P.H. Milburn, A.A. Maclean, and G.P. Demerchant. 1990. Intensive potato production effects on nitrate- $\mathrm{N}$ concentration of rural New Brunswick well water. Can. J. Eng. 32:189-196.

Roberts, S., H.H. Cheng, and I.W. Butler. 1992. Recovery of starter nitrogent- 15 fertilizer with supplementarily applied ammonium nitrate of irrigated potato. Amer. Potato J. 69:309-314.

Roberts, S., H.H. Cheng, and F.O. Farrow. 1991. Potato uptake and recovery of $\mathrm{N}-15$ enriched $\mathrm{NH}_{4} / \mathrm{NO}_{3}$ from periodic applications. Agron. J. 83:378-381.

Saravitz, C.H., F. Devienne-Barret, C.D. Raper, S. Chaillou, and T. Lamaze. 1998. Nitrate uptake rate by soybean and wheat plants determined by external nitrate concentration and shoot-mediated demand. Intl. J. Plant Sci. 159:305-312.

Sattelmacher, B. and H. Marschner. 1978. Nitrogen nutrition and cytokinin activity in Solanum tuberosum. Physiol Plant. 42:185-189.

Savvas, D. and K. Adamidis. 1999. Automated management of nutrient solutions based on target electrical conductivity, $\mathrm{pH}$, and nutrient concentration ratios. J. Plant Nutr. 22:1415-1432.

Struik, P.C., M.F. Askew, A. Sonnino, D.K.L. Mackerron, U. Bang, E. Ritter, O.J.H. Statham, M.A. Kirkman, and V. Umaerus. 1997. Forty years of potato research: Highlights, achievements, and prospects. Potato Res. 40:5-81.

Stutte, G.W. 1996. Nitrogen dynamics in the CELSS breadboard facility at Kennedy Space Center. J. Life Support Biosphere Sci. 3:67-74.

Sweetlove, L.J. and S.A. Hill. 2000. Source metabolism dominates the control of source to sink carbon flux in tuberizing potato plants throughout the diurnal cycle and under a range of environmental conditions. Plant Cell Environ. 23:523-529.

van Beusichem, M.L., E. Kirby, and R. Baas. 1988. Influence of nitrate and ammonium nutrition on the uptake, assimilation, and distribution of nutrients in Ricinus communis. Plant Physiol. 86:914-921.

Waddell, J.T., S.C. Gupta, J.F. Moncrief, C.J. Rosen, and D.D. Steele. 1999. Irrigation and nitrogen management effects on potato yield, tuber quality, and nitrogen uptake. Agron J. 91:991-997.

Walker, R.L., I.G. Burns, and J. Moorby. 2001. Responses of plant growth rate to nitrogen supply: A comparison of relative addition and N interruption treatments. J. Expt. Bot. 52:309-317.

Wan, W.Y., W. Cao, and T.W. Tibbitts. 1996. Tuber initiation in hydroponically grown potatoes by alteration of solution $\mathrm{pH}$. HortScience 26:621-623.

Went, F. 1957. The experimental control of plant growth. Chronica Botanica Co., Waltham, Mass.

Westermann, D.T. and G.E. Kleinkopf. 1985. Nitrogen requirements of potatoes. Agron J. 77:616-621.

Westermann, D.T., G.E. Kleinkopf, and L.K. Porter. 1988. Nitrogen efficiencies of potatoes. Amer. Potato J. 65:377-386.

Wheeler, R.M., C.L. Mackowiak, J.C. Sager, W.L. Berry, W.M. Knott, and C.R. Hinkle. 1990. Potato growth and yield using nutrient film technique (NFT). Amer. J. Potato Res. 67:177-187.

Wheeler, R.M., J.C. Sager, W.L. Berry, C.L. Mackowiak, G.W. Stutte, and N.C. Yorio. 1999. Nutrient, acid and water budgets of hydroponically grown crops. In: A.P. Papadpoulos (ed.). Proc. Intl. Symp. Growing Media and Hydroponics, Acta Hort. ISHS 481:655-661.

Zvomuya, F. and C.J. Rosen. 2002. Biomass partitioning and nitrogen use efficiency of 'Superior' potato following genetic transformation for resistance to Colorado potato beetle. J. Amer. Soc. Hort. Sci. 127:703-709. 